\title{
Trade Reforms, Farm Productivity, and Poverty in Bangladesh
}

\author{
Irina Klytchnikova and Ndiame Diop* \\ International Trade Department \\ The World Bank \\ MSN MC2-201 \\ 1818 H Street St. NW \\ Washington DC 20433 \\ Tel: (202) 473-8213, Fax: (202) 522-7551 \\ Email: klytchnikova@worldbank.org \\ ndiop@worldbank.org
}

\begin{abstract}
This paper analyzes the distributional impacts of trade reforms in rural areas of Bangladesh. The liberalization of trade in irrigation equipment and fertilizer markets during the early 1990s has led to structural changes in the agricultural sector and a significant increase in rice productivity. A resulting increase in output has been associated with a decline in producer and consumer rice prices of approximately 25 percent. Using a combination of ex-post and ex-ante approaches, we investigate the implications of the changes in rice productivity and prices for the welfare of households. We find that the net effects of increased rice productivity and lower rice price benefited the poor. Regardless of the particular category analyzed, the poorest households emerged as being particularly positively affected by reforms in the 1990s. This mainly reflects the fact that they are predominantly net rice buyers in both urban and rural markets. In contrast, large net sellers of rice, among the better-off households in the rural areas, were the main losers. Since net buyers in rural areas tend to be poorer than net sellers, trade liberalization has benefited the poor. Although we are not able to test empirically what has happened to the welfare level of agricultural wage earners, secondary evidence suggests that they have gained from trade liberalization.
\end{abstract}

\section{World Bank Policy Research Working Paper 3980, August 2006}

The Policy Research Working Paper Series disseminates the findings of work in progress to encourage the exchange of ideas about development issues. An objective of the series is to get the findings out quickly, even if the presentations are less than fully polished. The papers carry the names of the authors and should be cited accordingly. The findings, interpretations, and conclusions expressed in this paper are entirely those of the authors. They do not necessarily represent the view of the World Bank, its Executive Directors, or the countries they represent. Policy Research Working Papers are available online at http://econ.worldbank.org.

* This research has been funded by the Dutch Government under the BNNP grant "Agricultural Trade Reforms and Their impact on Rural Poverty.” The authors are grateful to Ataman Aksoy, Aylin Isik-Dikmelik, Ramon Lopez and an anonymous referee for helpful comments and discussion. 


\section{Introduction}

Bangladesh's economy underwent major structural transformation over the last two decades. While the garment sector has emerged as an important source of income, employment and export earnings and, in the rural areas, rural-non farm activities have grown in importance, both as a source of livelihood and income (World Bank 2004). Yet the agricultural sector has also changed dramatically, and has now become more productive than ever in Bangladesh's history. These structural transformations reflect the government's efforts to open the economy and liberalize domestic markets of the 1980s and 1990s (Mujeri 2002, Dorosh 2001). They have enabled Bangladesh to obtain a robust economic growth in the 1990s. Between 1991 and 2000, real GDP increased by 60 percent. In spite of this impressive growth performance however, the decline in the national incidence of poverty stood at a mere 9 percent, leaving poverty levels stubbornly high. In 2000, about half of the Bangladeshi population, or about 63 million people, lived below the official poverty line.

Many studies have attempted to shed light on the somewhat timid response of poverty to growth performance over the 1990s. Mujeri (2002) noted that globalization is a major feature of Bangladesh's economy since the 1980s and analyzed the impact of trade liberalization efforts on growth and poverty. Using a computable general equilibrium (CGE) model, he found that while Bangladesh's greater integration into the world economy has been generally “pro-poor”, the gains are relatively small due to the presence of structural bottlenecks and other constraints. The World Bank (2002) study stressed the importance of disaggregating growth and poverty by region and showed that the benefits of economic growth during the 1990s had not been distributed evenly across regions. In the same vein, another study (World Bank 2004) shows that the aggregate numbers hide important distributional effects across income levels and employment type. Indeed, the 1990s have seen an increased mobility of labor from farm to non-farm jobs and an improvement in rural agricultural wages (Hossein 2003). This rise in agricultural wages has tremendous impact on the poorest households who are disproportionately concentrated in this segment of the labor market.

This paper contributes to this literature by drilling further down in explaining poverty dynamics in the 1990s. We use a combination of ex-post and ex-ante approaches 
to investigate the links between agricultural productivity improvements and declining rice prices in Bangladesh and the trends in poverty and inequality in rural areas. Our premise is that despite the declining role of agriculture in Bangladesh, policies directed at this sector are still a major direct vehicle to reduce poverty. Over half of Bangladesh's working population still depends on agriculture for livelihood and income and the sector's contribution to overall growth is still important. Because rice constitutes over half of real agriculture GDP and about 15 percent of total monthly expenditures of Bangladeshi households, any policy change that affects the rice economy is bound to have important poverty impacts.

A major case in point are the trade liberalization policies and deregulation in agriculture that peaked in the early 1990s. The reform measures included liberalization of the input markets for fertilizer and irrigation equipment. In a gradual process, the government removed restrictions on imports of small diesel engines in 1987 and eliminated the duty on such imports in 1989. Deregulation and privatization of public tubewell installations and removal of restrictions on import of minor irrigation engines and pumps led to a rapid spread of farmer owned and operated small-scale irrigation in Bangladesh. That led to a large-scale shift to higher yielding rice varieties and a seasonal shift in favor of the irrigated winter (boro) rice crop, boosting rice productivity and agricultural growth. Internal and external trade liberalization efforts, combined with wider application of fertilizer and increased adoption of the higher yielding boro rice variety have led to a faster growth rate of rice production than population, allowing Bangladesh to achieve self-sufficiency in rice (Dorosh 2004, Ahmed and Sattar 2003, World Bank 2002b). The rising volume of rice production has been accompanied by a decline in rice prices throughout the last two decades. Only from 1995 until 2000, real producer and consumer prices of rice have fallen by average of between 22 and 27 percent (Appendix Figure A1).

The links between trade liberalization and poverty are complex. Trade liberalization measures can affect multiple actors, markets and institutions in the economy, and neither these effects nor the poverty level itself are static or easily measured. As pointed out by Winters (2002), some of these effects can be positive and others negative, especially in the short term, causing ambiguity with respect to the overall 
effect on poverty. Considering the channels through which trade measures affect poverty outcomes enables an assessment of the likely overall poverty impact of a specific trade liberalization measure.

Some categories of rural households have experienced significant income growth between 1995 and 2000. We do not simulate the effect of trade reforms in a general equilibrium model, as we have a natural experiment and we know what happened to rice prices and productivity. The productivity improvement was mainly a result of liberalization of the input markets in Bangladesh, as documented in the literature (Dorosh 2004, Ahmed and Sattar 2003, World Bank 2002b, Gisselquist and Harun-ar-Rashid 1998), and this improvement is a starting point in our analysis.

This paper is a mapping of gains and losses experienced by different types of rural households as a result of these changes, and an examination of the pathways through which these changes seem to have affected income levels. Thus, in this paper we do not directly test the link between trade reforms and poverty, but we assess the distribution of the income gains among rural households that resulted from productivity improvements and we show which channels seem to have affected different household groups and in particular the poor. We find that the net effects of increased rice productivity and lower rice prices have been extremely pro-poor. Regardless of the particular category analyzed, the poorest households emerged as being particularly positively affected by reforms in the 1990s. This mainly reflects the fact that they are predominantly net rice buyers in both urban and rural markets. In contrast, large net sellers of rice, among the better-off households in the rural areas, were the main losers.

The next section presents some theoretical insights on how net buyers, net sellers and agricultural wage earners are likely to be affected by trade reforms and particularly by improved technology in agriculture. The third section describes data sources and the extent of price and productivity changes. The fourth section presents the results of an exante simulation of the partial impact of the reforms. The fifth section is an ex-post examination of income growth for different categories of households and the channels through which this growth seemed to occur. The last section draws major conclusions of the paper. 


\section{The welfare effects of improved technology: theoretical insights}

Trade liberalization measures have opened new markets for small-scale irrigation equipment in Bangladesh and led to a substantial growth in rice productivity, so in this paper we focus on links between productivity-enhancing trade liberalization measures and household welfare. Ceteris paribus, productivity gains improve producer welfare because their positive effect on profits. However, productivity improvements may also translate into lower output prices, for example when domestic markets are segmented, which in turn has a negative effect on producer welfare.

Households may purchase or sell rice at different times of year, but over the course of the year they can be defined as net rice suppliers or net rice consumers. In order to explain the implications of increasing agricultural productivity and declining rice prices on household welfare, we make a distinction between net sellers and net buyers of rice. We also define one additional category of rural households: agricultural wage earners. Conceptually, the welfare effects of productivity improvements will be different for these three categories.

The first link between trade liberalization and welfare can be established through the direct effect of trade-related measures on crop prices and productivity, and we refer to this channel as direct first-round effect. The direct first-round effect of a single price change on household welfare is proportional to its net supply position in that good, valued at current prices and as a share of total expenditure. Declining price levels have a positive impact on net buyers and a negative impact on net sellers of rice. Formally, this has been described by Deaton (1989) in his pioneering study of the welfare effects of an increase in rice prices in Thailand and subsequently used in many empirical studies of welfare effects of price changes on farm households (e.g., Benjamin and Deaton 1993, Barrett and Dorosh 1995, Seshan 2005).

A productivity improvement has no direct effect on net buyers, but it affects profit levels of net sellers. For net sellers, technical change causes income to increase as long as elasticity of output with respect to technical change is greater than elasticity of price with respect to technical change (e.g., Barret and Minten 2005). Intuitively, if output increases faster than the price falls in response to technical change, net sellers will enjoy higher income and welfare even if some of the gains accrue to net buyers. If market prices have 
fallen, the only way for net sellers to gain is to have productivity increased faster than the rate of decline in prices. The net effect on net sellers depends on the magnitude of these two effects induced by technical change.

The second link between productivity-enhancing trade liberalization measures and welfare can be established through second-round direct effects, resulting from price- and productivity-induced changes in the rural labor market. Technical change is likely to increase marginal physical productivity of labor, but this marginal output is often valued at a lower price. So if marginal physical product of labor increases faster than prices fall in response to technical change, employment and wages rise, benefiting agricultural wage earners. Employment and wages adjust in the same direction as the marginal revenue product of labor, so the key question for understanding the direction of the welfare effect on agricultural wage earners is whether technical change raises or reduces the marginal revenue product of labor (Minten and Barrett 2005).

A change in productivity and prices has a further effect on agricultural households. In developing countries with imperfect labor markets households often work on their own farm, either in market or subsistence agriculture, rather than working for a wage in the agricultural or non-agricultural sectors. Changes in agricultural prices and productivity, induced by trade liberalization, can affect the implicit trade-off between family work and wage employment and switch employment between these two employment types. Thus, a household's net sales position could change following trade reforms because of labor market response. This observation demonstrates that static analysis of the first-round effects without accounting for labor market response is an inaccurate assessment of the actual welfare change (De Janvry et. al. 1995, Porto 2005). To sum up, trade-related measures may affect the probability of employment in wage labor as well as the wage rates, both of which can have important ramifications for the poverty status of a household (De Janvry et. al. 1995, Edmonds and Pavcnik 2004, Minten and Barrett 2005, Nicita 2005, Seshan 2005).

The third link is the effect of trade liberalization on non-agricultural markets and employment opportunities in rural areas through spending spill-over effects. This phenomenon has been referred to as the consumption growth multiplier of trade liberalization measures (Delgado et. al. 1998, Winters 2002). In the early studies of the 
poverty impact of agricultural growth, multiplier effects were understood as agricultural backward and forward production linkages, i.e. increased demand for production inputs and demand for processing services. These linkages were thought to be small and investment in non-agricultural "growth poles" was considered to be more important for stimulating overall growth than investments in agriculture. But the experience of the Green Revolution in India changed this paradigm and led to the recognition during the 1960s and 1970s that agriculture could be a motor for overall growth due to its effect on rural incomes and the rising consumer demand for goods and services outside agriculture (Delgado et. al. 1998).

A distinction between tradable and non-tradable goods is crucial in an examination of the magnitude of spending spill-over effects (Siamwalla 1982). The nontradable goods category includes farm and non-farm items that are not traded, such as services and perishable foods. Growth in spending on these items stimulates local services and industries, resulting in sizable spill-over effects, in contrast to the effects of increased consumption of tradable goods. Spending multipliers can be estimated in a general equilibrium model. Alternatively, these multipliers can be calculated in a partial equilibrium framework if the origin of the expenditure items were known, i.e. whether they are associated with the purchase of tradable or non-tradable goods and services. Several studies have indicated that consumption multipliers could account for a notable change in rural incomes (e.g., Delgado et. al. 1998, Winters 2002).

The extent to which direct or indirect effects of productivity changes predominate depends on the nature of poverty, the nature of technological changes, and the economic and institutional context in the regions where technological improvements take place. In order to assess the likely magnitude of these two types of effects on the poor, whether technological improvements are caused by trade liberalization measures or not, De Janvry and Sadoulet (2002) propose an analytical framework and describe the conditions when the direct or indirect effects are likely to dominate. Direct effects are defined as the rising welfare from higher production for home consumption and higher profits for poor farmers who adopt the technological innovation. Indirect effects in this framework occur through the price of food for consumers, employment and wage effects in agriculture, and 
employment, wage and income effects in other sectors of economic activity though different types of linkages which we have defined as the multiplier effects.

Using this conceptualization of direct and indirect effects, De Janvry and Sadoulet (2002) define an archetype computable general equilibrium model for representative African, Asian and Latin American countries and compare the likely magnitude of direct and indirect effects of technological innovation in agricultural production. In a typical African country with a traditional agrarian economy direct effects are likely to be more significant than indirect effects, in Asia indirect agricultural employment effects are likely to be large as countries in this region tend to have large numbers of landless rural households, and in Latin America the dominant effect on poverty is likely to be through linkage effects through the rest of the economy. In practice, whether direct or indirect effects have a stronger impact on poverty is an empirical question.

As De Janvry and Sadoulet (2002) conclude, direct effects on farmers' agricultural incomes and indirect effects through a declining price of food for others, need not be the dominant effects. Labor market and multiplier effects could dominate the price and productivity effects when poor rural households have diversified sources of income, including wage labor in agriculture or in non-agriculture. Although the categorization of the various effects of productivity improvement on the welfare of the poor is slightly different from this paper, the channels we consider are the same as in this earlier study. A close look at the change in the income structure of Bangladeshi households in this paper sheds some light on the likely contribution of various components of the overall welfare effect of rice productivity improvements.

The welfare impacts of increased productivity are heterogeneous owing to variability in the local conditions ranging from climate and local labor markets to access to credit, inputs and the quality of local institutions. Hence, in this paper we maintain a regional focus on poverty and agricultural productivity dynamics in Bangladesh regions with different agro-climatic conditions. While we recognize the importance of all three channels through which trade affects household welfare (i.e., direct first-round effects, direct second-round effects and multiplier effects), we only provide partial estimates of the first-round direct effects and investigate secondary evidence about the significance of multiplier effects. Due to data constraints, we are not able to estimate the multiplier 
effects or even the direct second-round effects of trade liberalization operating through the labor market. We adopt a combination of ex-ante and ex-post approaches. In the exante simulations we assess the extent to which first-round direct effects have contributed to poverty reduction across heterogeneous household categories. In ex-post analysis we describe the income growth trend of the same groups of households and provide some possible explanations for the observed income change.

\section{Background and data}

The data in this paper are stemming from the 1995-96 and 2000 Household Income Expenditure Surveys (HIES) of Bangladesh. We use the 1995-96 survey in the ex-ante simulations and both surveys in the ex-post analysis. The same communities, or thana as they are called in Bangladesh, are included in both rounds of this repeated cross-section survey, enabling us to combine the two data sets in a single community-level panel data set. Although it would be preferable to have an individual-level panel data set, thanalevel panel allows us to control for unobserved heterogeneity by community when we examine the trends in producer and consumer prices of rice, production volume, and rice yields.

Although the sampling frame has not changed, significant modifications in the questionnaire design result in poor comparability of households according to some dimensions. That is particularly true of the questions about the total area of land cultivated and about agricultural production, which are of crucial importance in our analysis. In particular, the calculated change in yields is highly sensitive to changes in the size of cultivated area and should be interpreted with caution. Thus, average yields calculated from the thana-level panel are sensitive to the presence of outliers. ${ }^{1}$ These data comparability issues and our approach to resolving some of them are described in Appendix 2. We resolved some of these issues and developed a consistent definition of farming household in both surveys. Due to the remaining unresolved survey comparability issues, such as the absence of a consistent definition of agricultural wage earners, we are unable to conduct a detailed analysis of the welfare effect of price and productivity changes on this category of households.

\footnotetext{
${ }^{1}$ This effect persists even after cleaning the data by dropping observations over 5 standard deviations from the mean of the data.
} 
Bangladesh produces three crops of rice per year: aman is typically planted during the summer prior to the onset of monsoon rains and harvested in the winter, aus is planted in the spring and harvested in the summer, and a high-yielding irrigated rice variety, boro, planted in the winter and harvested in the spring or early summer (Del Ninno et. al. 2003). As revealed by the 1995-96 and 2000 HIES, the most notable change in the agricultural sector in Bangladesh in the recent years is a significant increase in the production of boro rice, made possible by the wider availability of small-scale imported irrigation equipment following trade liberalization. The shift is particularly pronounced in South Ganges Flood Plain and East Hills regions with an 18 and 15 percentage point increase in the share of boro, respectively. ${ }^{2}$ The increase in the boro production share in the North Central, Meghna Flood Plain and Northwest regions has been in the range of 10 percentage points, and the smallest change is observed in the Coastal region (Figure 1).

Figure 1. Change in rice production structure, 1995-2000.

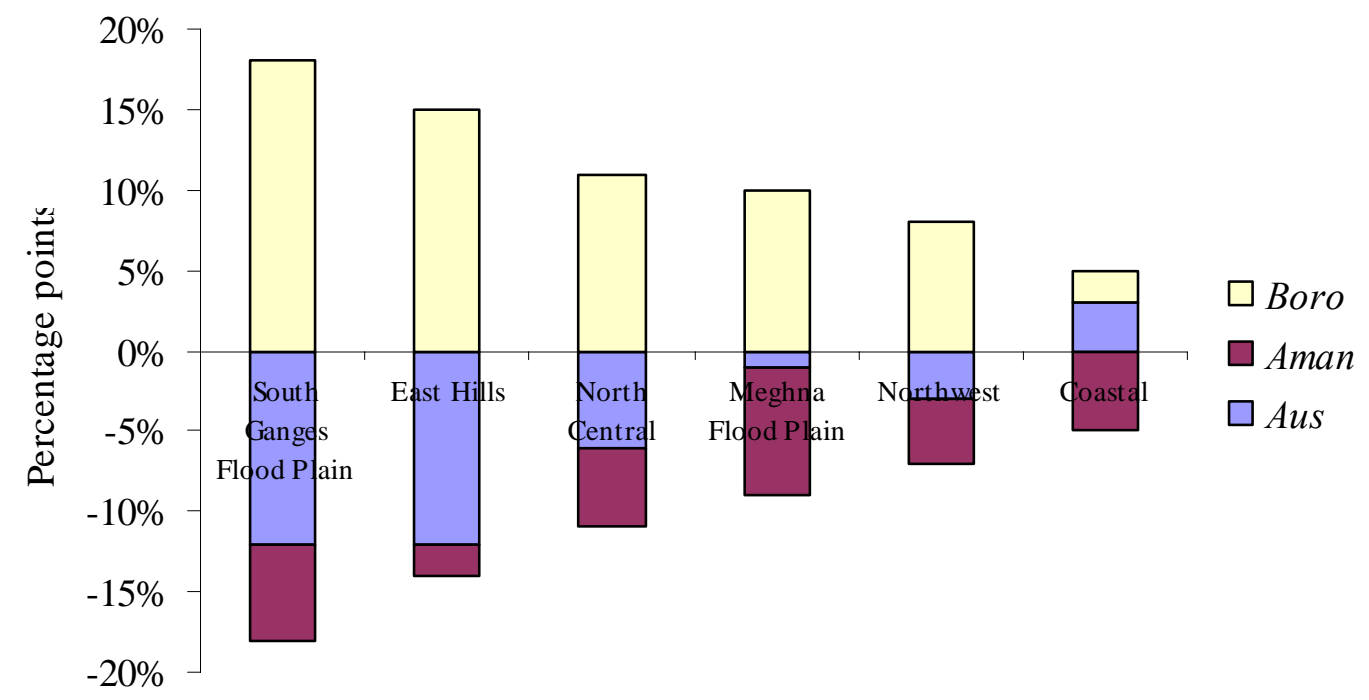

Note: Change in percentage points was calculated by subtracting the shares of rice by variety in total rice production in 2000 from 1995-96. Calculated from summary statistics in the two household-level data sets. Source: 1995-96 and 2000 HIES.

\footnotetext{
${ }^{2}$ In order to capture some of the regional diversities, six broad agro-ecological regions were constructed, following the classification by World Bank (2000b). These regions were created in accordance with several major criteria: consistency with broad agro-ecological zones, hydrological regions, division boundaries, and the need to limit the number of regions to get a statistically representative sample from the Household Income and Expenditure Survey (HIES 2000) for the region (see Appendix Map 1).
} 
A shift in favor of boro cultivation has led to a significant increase in rice production due to the much higher yields of the boro variety. As Table 1 clearly shows, boro rice has nearly three times higher yields than aus, and two times higher than aman. Due to differences in environmental conditions, these yield differentials exhibit strong regional variation. Summary statistics from thana-level panel indicate a significant increase in rice productivity between 1995-96 and 2000, with total annual production per acre rising by an average of 42 percent at the median (Appendix Table A1). ${ }^{3}$ According to the Bangladesh Bureau of Statistics (BBS), total aggregate production of rice rose by 30 percent in the period from 1995-96 to 1999-2000 and by 42 percent between 1995-96 and 2000-2001, validating the observed increase from survey data (Dorosh 2004).

Table 1. Yields of aus, aman and boro rice in Bangladesh.

\begin{tabular}{lccccc}
\hline & \multicolumn{3}{c}{ Yields (kg/acre) } & \multicolumn{2}{c}{ Yield ratios } \\
& Aus & Aman & Boro & Boro/Aus & Boro/Aman \\
\hline Northwest & 0.47 & 0.73 & 1.37 & 2.91 & 1.88 \\
South Ganges Flood Plain & 0.45 & 0.53 & 1.51 & 3.36 & 2.85 \\
Coastal & 0.43 & 0.50 & 1.29 & 3.00 & 2.58 \\
North Central & 0.40 & 0.63 & 1.24 & 3.10 & 1.97 \\
Meghna Flood Plain & 0.52 & 0.73 & 1.09 & 2.10 & 1.49 \\
Eastern Hills & 0.55 & 0.71 & 0.84 & 1.53 & 1.18 \\
All Bangladesh & 0.46 & 0.64 & 1.25 & 2.72 & 1.95 \\
\hline
\end{tabular}

Source: Calculated from Bangladesh Bureau of Statistics annual data, which are reported in World Bank (2002b).

Productivity improvement has had dramatic consequences for rice harvests. While average production volume was approximately 15 million tons during 1980-90 and 18.8 million tons during 1990-2000, it exceeded an average of 24.9 million tons during 20002003. The significantly higher level of rice production in the 2000 HIES than in the 199596 HIES is largely a result of policies that allowed a shift to high-yielding rice varieties and to irrigated boro rice rather than solely being a consequence of weather differences between these two survey years (Dorosh 2004, Del Ninno and Dorosh 2003, World Bank 2002b).

\footnotetext{
${ }^{3}$ While this increase seems realistic given the changes in crop intensity of boro production and the yield differential between boro and the other rice varieties, the mean increase of nearly 80 percent (not shown) is much less realistic. The mean is heavily influenced by the outliers in a community-level panel, and they have far greater weight in the panel data set with slightly over 200 communities than in a household panel of over 5,000 observations in each year.
} 
Producer and consumer rice prices have declined by an average of 22 to 27 percent, although in some regions the price change exceeds one-third (Table 2). It is not clear to what extent the observed decline in rice prices is a result of higher productivity, although there is a strong correlation between rice production volume and rice prices in Bangladesh. Thus, Dhaka wholesale price of rice was consistently below the import parity price except for a brief period in 1998 and 1999 following production shortfalls after a flood and a drought (Dorosh 2004).

Table 2. Change in the price of rice paddy and consumer prices, 1995-96 to 2000.

\begin{tabular}{lcc}
\hline & $\begin{array}{c}\text { Producer price of rice } \\
\text { (\% change) }\end{array}$ & $\begin{array}{c}\text { Consumer price of rice } \\
\text { (\% change) }\end{array}$ \\
\hline Northwest & $-22 \%$ & $-18 \%(-20 \%)$ \\
Ganges Floodplain & $-23 \%$ & $-20 \%(-22 \%)$ \\
Coastal & $-28 \%$ & $-23 \%(-28 \%)$ \\
North Central & $-15 \%$ & $-19 \%(-21 \%)$ \\
Meghna Floodplain & $-31 \%$ & $-30 \%(-36 \%)$ \\
East Hills & $\mathrm{Na}$ & $-34 \%(-42 \%)$ \\
All Bangladesh & $-23 \%$ & $-22 \%(-27 \%)$ \\
\hline
\end{tabular}

Note: The East Hills region is excluded because it is a minor area of rice cultivation and is not statistically representative. Numbers in brackets are averages from household-level data set. Source: calculated from the community-level panel using 1995-96 and 2000 HIES.

Rather significant variation of the extent of price change in different communities, observed in Table 2, is caused by different demand and supply conditions and the degree of integration into national and international markets for rice in these communities. The discrepancy between the two price indexes and a strong correlation between domestic rice prices and production volume suggests that rice can be regarded as a non-tradable commodity in Bangladesh. Hence, we assume in this paper that the decline in rice prices is largely a result of growth in production rather than international price fluctuations.

\section{Ex-ante simulation of the welfare effects of rice price decline}

Rice is a major source of income in rural Bangladesh. While crop income constitutes 18 percent of total income, revenues from rice production alone are 13 percent of total household income. Rice accounts for 75 percent of the total crop production value and 63 percent of total crop sales, and cultivated area under rice ranges from 63 to 84 percent of total cultivated area in the country (World Bank 2002b: Annex p.33). Rice is also the 
single most important consumption item of both urban and rural households in Bangladesh. Rice purchase outlays average 12 percent of total monthly expenditures for urban households and 15 percent for the rural households, with a significant difference by household's welfare level. As shown in Table 3, in rural areas rice purchases constitute around 22 percent of total expenditures of households in the bottom decile of total per capita expenditures, while they are 3 percent for households in the top decile. In addition to purchases, own consumption of self-produced rice accounts for about 6 to 11 percent of total expenditures for rural households at different welfare levels.

Table 3. Dependence on rice in rural areas in Bangladesh.

\begin{tabular}{|c|c|c|c|c|c|c|c|c|c|c|}
\hline & \multicolumn{10}{|c|}{ Deciles of total per capita expenditures } \\
\hline & 1 & 2 & 3 & 4 & 5 & 6 & 7 & 8 & 9 & 10 \\
\hline \multicolumn{11}{|c|}{ (percent of all households) } \\
\hline Net buyers of rice & 87 & 80 & 78 & 76 & 68 & 71 & 66 & 59 & 60 & 65 \\
\hline Net sellers of rice & 10 & 17 & 18 & 21 & 28 & 24 & 29 & 35 & 34 & 30 \\
\hline $\begin{array}{l}\text { Agricultural wage } \\
\text { earners }\end{array}$ & 41 & 34 & 23 & 21 & 14 & 13 & 8 & 3 & 3 & 1 \\
\hline Landless households & 71 & 62 & 58 & 54 & 44 & 46 & 42 & 34 & 30 & 40 \\
\hline \multicolumn{11}{|c|}{ (percent of total income or expenditures) } \\
\hline $\begin{array}{l}\text { Income from rice } \\
\text { production }\end{array}$ & 9 & 12 & 12 & 13 & 16 & 14 & 16 & 17 & 16 & 12 \\
\hline \multicolumn{11}{|l|}{ Expenditures on rice: } \\
\hline $\begin{array}{l}\text {-purchased } \\
\text {-self-produced }\end{array}$ & $\begin{array}{c}35 \\
6\end{array}$ & $\begin{array}{c}28 \\
8\end{array}$ & $\begin{array}{l}25 \\
10\end{array}$ & $\begin{array}{c}23 \\
9\end{array}$ & $\begin{array}{l}20 \\
10\end{array}$ & $\begin{array}{l}17 \\
10\end{array}$ & $\begin{array}{l}16 \\
10\end{array}$ & $\begin{array}{l}12 \\
11\end{array}$ & $\begin{array}{c}9 \\
10\end{array}$ & 7 \\
\hline $\begin{array}{l}\text { Note: Landless are defined } \\
\text { "Agricultural wage earners } \\
\text { occupation is agricultural } \\
\text { Source } 2000 \text { HIFS (onlv }\end{array}$ & & Ial & & & & & & & & \\
\hline
\end{tabular}

When all rural households in Bangladesh are categorized into rice net sellers and net buyers, we find that, as expected, poverty incidence is higher among the net buyers than among the net sellers, with a 16 percentage point difference in poverty rates (Appendix Table A2). On average, 34 percent of Bangladeshi rural households can be classified as the net sellers of rice, with a strongly pronounced declining share of net buyers and increasing share of net sellers with income (Table 3). Half of rural households in Bangladesh are functionally landless, and on average 20 percent are agricultural wage earners. As expected, the share of landless households and agricultural wage earners among all rural households declines with income. Income from rice production is 
substantially higher for middle-income households than either for the households in the bottom three or in the top decile of total per capita expenditures. However, these averages hide substantial variation by region. As shown in Table 4, rice production revenues constitute the highest share of total income in the Northwest, North Central and South Ganges Floodplain regions. ${ }^{4}$

Table 4. Spatial Profile of Rural Poverty and Dependence on Agriculture.

\begin{tabular}{|c|c|c|c|c|c|c|}
\hline & $\begin{array}{l}\text { North- } \\
\text { west }\end{array}$ & $\begin{array}{l}\text { South } \\
\text { Ganges } \\
\text { FPLN }\end{array}$ & $\begin{array}{l}\text { North } \\
\text { Central }\end{array}$ & $\begin{array}{l}\text { Meghna } \\
\text { FPLN }\end{array}$ & $\begin{array}{l}\text { East } \\
\text { Hills }\end{array}$ & $\begin{array}{c}\text { Coastal } \\
\text { Area }\end{array}$ \\
\hline \multicolumn{7}{|l|}{ Headcount rates, } \\
\hline $\begin{array}{l}\text { Headcount rates, } \\
\text { LPL, } 2000(\%)\end{array}$ & 49 & 49 & 37 & 26 & 21 & 25 \\
\hline \multicolumn{7}{|c|}{ (percent of total household gross income) } \\
\hline $\begin{array}{l}\text { Agricultural wage } \\
\text { income }\end{array}$ & 22 & 18 & 15 & 10 & 11 & 14 \\
\hline Farm income & 27 & 28 & 22 & 14 & 13 & 18 \\
\hline $\begin{array}{l}\text { Crop production } \\
\text { revenues }\end{array}$ & 24 & 22 & 18 & 11 & 11 & 13 \\
\hline $\begin{array}{l}\text { Rice production } \\
\text { revenues }\end{array}$ & 17 & 13 & 14 & 9 & 9 & 10 \\
\hline $\begin{array}{l}\text { Non-agricultural } \\
\text { income }\end{array}$ & 30 & 34 & 38 & 37 & 40 & 36 \\
\hline
\end{tabular}

Note: Poverty headcount rates are individually weighted, and income structure statistics are weighted using the household weight. Agricultural income includes agricultural wages and production revenues. Nonagricultural income includes non-farm wage income and non-agricultural enterprise income. UPL denotes the upper poverty line, and LPL denotes the lower poverty line as defined by the Bangladesh Bureau of Statistics and reported in World Bank (2002a).

Source: HIES 2000, rural households.

Given the importance of rice in the income and consumption structure of Bangladeshi households, in particular in the main regions of rice cultivation, a productivity improvement and a price change of rice have a significant effect on the welfare of rice producing and rice consuming households alike. Indeed, the rapid expansion of irrigation and boro rice cultivation led to significant growth or rural per capita domestic product, particularly in the Northwest, South Ganges and North Central regions (World Bank 2002b). Before turning to the ex-post analysis, it is useful to

\footnotetext{
${ }^{4}$ In terms of the share of total production value three regions with the highest rice shares are the Meghna Floodplain, Northwest and North Central regions, according to HIES 2000. The South Ganges region has a somewhat lower share of rice in total production value (around 30 percent compared to between 43 and 51 percent in the other three regions).
} 
understand how real price decline affects different households, according to their degree of participation in the rice market. We use for this illustrative analysis Bangladesh's 1995 HIES.

In order to evaluate the overall welfare impact of price changes on households who are both rice producers and rice consumers, we use Deaton's (1989) methodology. The overall welfare effect of a rice price decline, assuming that the consumption and production prices decline by the same percentage, is directly proportional to the net benefit ratio (NBR). This ratio is the difference between the net consumption ratio (CR) and the net production ration (PR), and the short-run distributional effect of rice price changes is directly proportional to the share of rice in income and consumption (Deaton 1989, 1997):

$$
\frac{\Delta w}{x_{0}} \cong \frac{\Delta p_{r}^{p}}{p_{0 r}^{p}} P R_{r}-\frac{\Delta p_{r}^{c}}{p_{o r}^{p}} C R_{r},
$$

where $\Delta w$ is the first-order approximation of the net welfare effect of a rice price change on a household and the superscripts $p$ and $c$ are used to distinguish between the prices used to value rice production and consumption, respectively, PR and CR denote the production and consumption ratios, and $x_{0}$ is total household budget.

The longer-term direct welfare effect can be calculated using a Taylor series approximation, and it accounts for household production adjustment in response to the price change ${ }^{5}$ :

$$
\frac{\Delta w^{2}}{x_{0}} \cong \frac{\Delta p_{r}^{p}}{p_{0 r}^{p}} P R_{r}+\frac{1}{2}\left(\frac{\Delta p_{r}^{p}}{p_{0 r}^{p}}\right)^{2} P R_{r} \varepsilon_{r r}^{s}-\frac{\Delta p_{r}^{c}}{p_{o r}^{p}} C R_{r}-\frac{1}{2}\left(\frac{\Delta p_{r}^{p}}{p_{0 r}^{p}}\right)^{2} C R_{r} \varepsilon_{r r}^{H},
$$

where $\Delta w^{2}$ is the second-order approximation of the net welfare effect of a rice price change on a household, and $\varepsilon^{s}$ and $\varepsilon^{H}$ are the elasticity of supply and demand, respectively. By adding the second and fourth terms on the right hand side of the equation above, we are partially capturing the direct second-round effects of a rice price decline that include the price-induced response on the supply and demand side.

Table 5 shows that the impact of a rice price decline varies across different household categories. Since most households even in the urban areas are net consumers

\footnotetext{
${ }^{5}$ See Minot and Goletti (2000) for a derivation. Minot and Goletti used this method to study the impact of rice price increase on welfare in Vietnam.
} 
of rice, they benefit from a decline in its price. Benefits are especially high for net buyers of rice, non-farmers and for the rural poor in the bottom 30 percent of total per capita household expenditures. Net sellers of rice and farmer households lose from the price decline, especially large farmers.

Table 5. Welfare impact of a 27 percent decline of rice prices, 1995-96 HIES.

Net benefit ratio
(NBR=CR-PR)

Simulated

short-run

welfare impact

(\% of total

expenditures)
Simulated

long-run

welfare impact

(\% of total

expenditures)
Actual income growth from 1995 to 2000 (\% of total expenditures)

$\begin{array}{lcccc}\text { Urban } & 13.2 & 3.6 & 4.1 & -5.7 \\ \text { Rural } & -1.8 & -0.5 & 1.3 & 4.0 \\ \text { All households } & 0.7 & 0.2 & 1.8 & \end{array}$

Rural only:

Bottom 30\%

Middle $40 \%$

Top 30\%

Net sellers

Net buyers

Non-farmers

All farmers

Small farmers

Medium

farmers

Large farmers
16.0

$-6.9$

$-18.8$

$-60.2$

21.0

19.1

$-25.2$

$-5.0$

$-40.9$

$-68.8$
4.3

$-1.9$

$-5.1$

$-16.3$

5.7

5.1

$-6.8$

$-1.3$

$-11.1$

Note: consumption and production includes the value of own consumption and production. Long-run scenario assumes elasticity of demand equal to -0.5 and elasticity of supply equal to 1.5 . Source: 1995 HIES.

An approximation of the long-term welfare effect that accounts for adjustments in household behavior yields higher gains and lower losses. The estimated welfare impact ranges from a loss of 14 percent for large farmers to a gain of nearly 7 percent of total expenditures for net buyers when rice price declines by 27 percent, as it did during the period from 1995-96 to 2000. The losses are especially high for medium and large farmers. 
In actuality, income growth for rural households has been stronger than predicted by the simulations even in the long run. Thus, the last column of Table 5 shows that income has increased by 4 percent during this period compared to the predicted 1.8 percent. Income growth has been particularly strong for households in the bottom 30 percent of total per capita expenditures and it has exceeded 9 percent for this group. Interestingly, income of farmers of all sizes has increased by 10.5 percent instead of the decline of 4.2 percent. The urban households are the only category that experienced a worse growth performance than what was predicted by the simulation: 5.7 percent decline instead of 4.1 percent growth. ${ }^{6}$

The discrepancy between the results of the ex-ante simulation and ex-post income growth could be due to several factors. The assumed demand and supply elasticities could actually be different. But even more importantly, the simulation has omitted the labor market and multiplier effects of a change in rice prices and productivity. Therefore, the simulated welfare impact is an overestimate of the losses on net sellers, particularly if they experience significant gains from an improvement in productivity, and it is an empirical question whether or not these gains outweigh the losses. The positive multiplier effects resulting from growth of the non-farm rural sector, particularly the service sector for the newly available irrigation equipment, further magnify welfare gains and mitigate losses of net buyers and net sellers. Hence, the direction of the true welfare impact could change if the omitted effects are sufficiently large.

\section{Ex-post analysis: dynamic welfare impacts of productivity and price changes}

A comprehensive evaluation of the impact of changes in rice prices and productivity on household welfare would include three components: the direct first-round effect of the price and productivity changes on net buyers and net sellers in rural and urban areas, the direct second-round effects brought about by labor market repercussions, and the multiplier effects of agricultural growth on rural and urban communities. Owing to data constraints, we are unable to estimate the magnitude of these effects in a structural model.

\footnotetext{
${ }^{6}$ The poor performance of income growth in the urban areas may be a result of migration from rural to urban areas. According to census results, the urban population in Bangladesh grew nearly four times as fast as the rural population in the 1990s, possibly contributing to the observed low growth rate of the incomes of the urban poor (World Bank 2002a). However, the focus of this paper is on rural population, and we do not examine this tendency in urban income growth any further.
} 
Instead, we pursue an in-depth examination of income growth from different sources and for different categories of households depending on their net position on the rice market and their welfare level. In an examination of these trends we rely on the insights provided by the growth incidence curves, which represent the changes in consumption expenditures of particular groups of population in the period between two household surveys (Ravallion 2004, Ravallion and Chen 2003).

Growth incidence curves, shown in Figures 2.5, reveal that all rural households have experienced a modest increase in total consumption, with the poor experiencing particularly strong income growth. Even among urban households and among rural net sellers, with an average decline in real income of about six percent, the poor have faired far better than the average. In rural areas, households in the bottom 20th to 30th percentile of per capita household expenditures have seen very strong income growth, whether they are net sellers, net buyers of rice, farmers, or non-farmers. ${ }^{7}$

Figures 2.5. Growth in consumption expenditures in Bangladesh, 1995-96 to 2000.
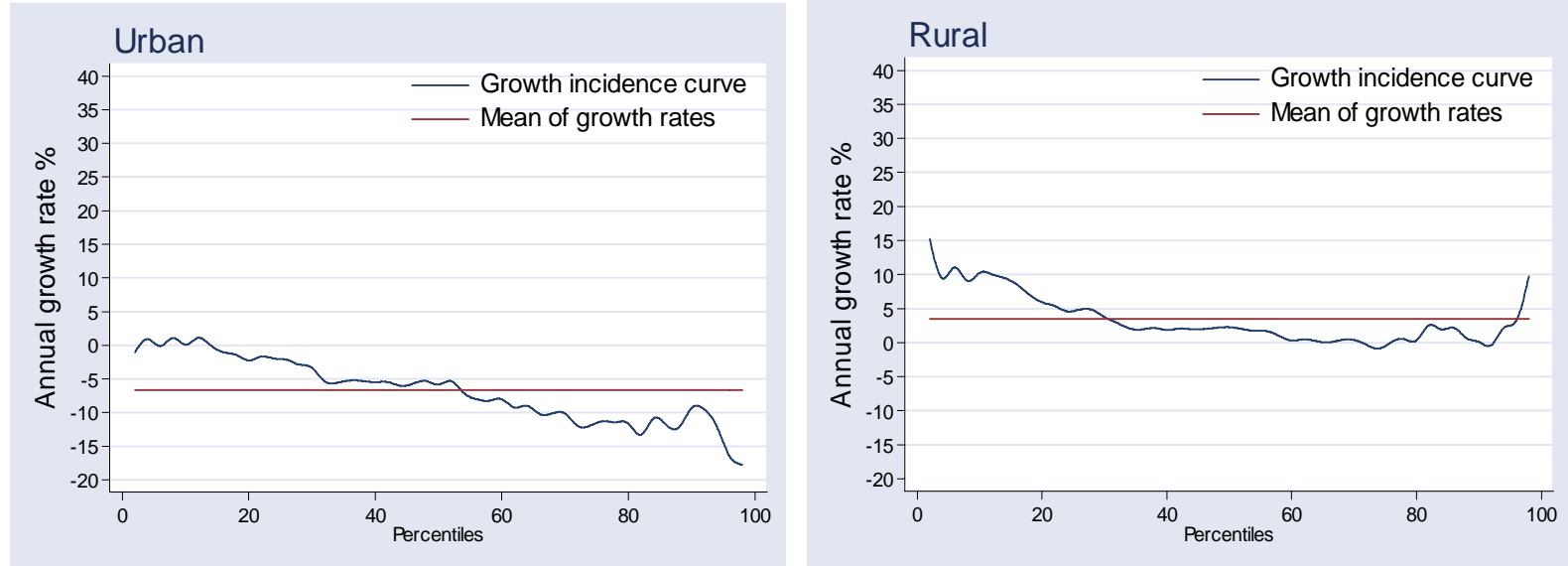

\footnotetext{
${ }^{7}$ Growth incidence curves for the farmers and non-farmers are not shown here, but they also indicate that expenditure growth has been positive and strong for the poor.
} 

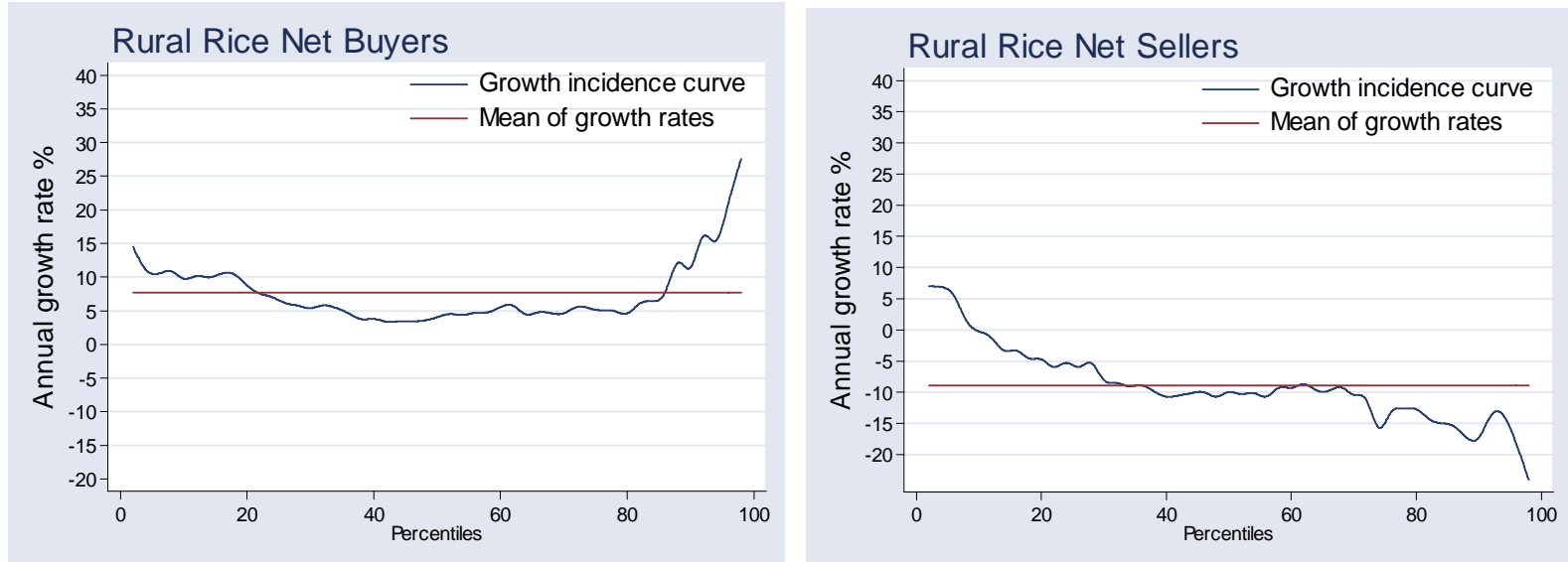

Note: The horizontal axis shows per capita expenditure groups from poorest to richest, in 2 percent increments. The bottom $30^{\text {th }}$ percentile is the poorest of the population in a specified category of households according to our definition. The vertical axis shows growth in expenditures between 1995-96 and 2000, in percent. The straight line shows the mean of the growth rates for all expenditure groups within a geographic area. Results are weighted by the individual weight. Source: calculated from household-level data from the 1995-96 and 2000 HIES.

This finding is reinforced by the results of a decomposition of growth in total expenditures. Using the income shares from the 2000 income structure and applying them to the expenditure growth figures in each of the six categories of households we analyze here, we examine the sources of growth. ${ }^{8}$ This approach could be thought of as a reduced-form measure of direct first- and second-round effects of a price and productivity change and multiplier effects. Table 6 clearly shows that poor households in the bottom $30^{\text {th }}$ percentile of total expenditures have experienced strong income growth, ranging from five percent for net sellers to 14 percent for rural non-farmers. Most of this growth among rural households is stemming from agricultural and non-agricultural wages and from other sources of non-agricultural income.

The agricultural growth multiplier effect might be captured by two income categories: non-agricultural wages and other income sources. Even though we do not attempt to calculate consumption growth multipliers, it is clear that spillover effects of agricultural growth on other sectors of the rural economy in Bangladesh account for a large share of income growth between 1995 and 2000. Trade liberalization and the

\footnotetext{
${ }^{8}$ This approach implicitly assumes that income growth has been homothetic, i.e. total growth can be decomposed simply in proportion to the share of each income source in the total income. This is a restrictive assumption, not likely to be satisfied in practice. However, this was the only feasible approach given the data constraints. A better approach would have been to examine the actual changes in income from each category, but we were not confident in the reliability of those results due to survey comparability issues, described in Appendix 2.
} 
resulting growth in agricultural productivity have increased demand for services, machinery repairs, small tractors and agricultural pumps in rural areas and brought about growth in non-farm employment opportunities (Winters 2002, World Bank 2004). The evidence presented here appears to corroborate this story in Bangladesh.

Table 6. Decomposition of growth in total expenditures, 1995-96 to 2000.

\begin{tabular}{|c|c|c|c|c|c|c|c|}
\hline & $\begin{array}{l}\text { Agricultural } \\
\text { wages }\end{array}$ & $\begin{array}{c}\text { Non- } \\
\text { agricultural } \\
\text { wages }\end{array}$ & Remittances & $\begin{array}{l}\text { Other } \\
\text { sources }\end{array}$ & $\begin{array}{l}\text { Agricultural } \\
\text { production } \\
\text { (gross) }\end{array}$ & $\begin{array}{c}\text { Of } \\
\text { which } \\
\text { Rice }\end{array}$ & $\begin{array}{l}\text { Total } \\
\text { growth, } \\
\text { percent }\end{array}$ \\
\hline \multicolumn{8}{|l|}{ Urban } \\
\hline Poorest 30\% & 0.5 & 3.2 & 0.1 & 2.2 & 0.2 & 0.1 & 6.3 \\
\hline Middle $40 \%$ & 0.0 & 0.7 & 0.1 & 0.5 & 0.1 & 0.0 & 1.3 \\
\hline Richest 30\% & 0.0 & -0.9 & -0.1 & -1.1 & -0.1 & 0.0 & -2.2 \\
\hline Total & -0.1 & -2.6 & -0.3 & -2.5 & -0.2 & -0.1 & -5.7 \\
\hline \multicolumn{8}{|l|}{ Rural } \\
\hline Poorest 30\% & 2.6 & 1.9 & 0.3 & 2.7 & 1.7 & 1.0 & 9.1 \\
\hline Middle 40\% & 0.1 & 0.2 & 0.0 & 0.3 & 0.2 & 0.1 & 0.8 \\
\hline Richest 30\% & 0.1 & 0.7 & 0.6 & 1.5 & 0.9 & 0.6 & 3.8 \\
\hline Total & 0.7 & 0.8 & 0.3 & 1.3 & 0.9 & 0.5 & 4.0 \\
\hline \multicolumn{8}{|c|}{ Rural net buyers } \\
\hline Poorest 30\% & 3.3 & 2.6 & 0.3 & 3.1 & 0.7 & 0.3 & 10.1 \\
\hline Middle 40\% & 0.3 & 0.4 & 0.1 & 0.5 & 0.1 & 0.0 & 1.4 \\
\hline Richest 30\% & 0.6 & 2.7 & 2.0 & 4.6 & 0.8 & 0.3 & 10.6 \\
\hline Total & 1.8 & 2.3 & 0.7 & 3.1 & 0.7 & 0.3 & 8.7 \\
\hline \multicolumn{8}{|c|}{ Rural net sellers } \\
\hline Poorest 30\% & 0.5 & 0.2 & 0.1 & 0.7 & 1.6 & 1.1 & 3.2 \\
\hline Middle 40\% & -0.4 & -0.5 & -0.2 & -1.3 & -2.7 & -1.8 & -5.1 \\
\hline Richest 30\% & -0.1 & -0.6 & -0.5 & -1.5 & -2.5 & -1.7 & -5.2 \\
\hline Total & -0.6 & -0.7 & -0.4 & -2.0 & -3.9 & -2.7 & -7.7 \\
\hline \multicolumn{8}{|c|}{ Non-farmers (rural) } \\
\hline Poorest 30\% & 4.8 & 3.6 & 0.5 & 4.4 & 1.0 & 0.5 & 14.3 \\
\hline Middle 40\% & 0.7 & 1.0 & 0.2 & 1.3 & 0.3 & 0.1 & 3.6 \\
\hline Richest 30\% & -0.2 & -0.8 & -0.6 & -1.4 & -0.1 & -0.1 & -3.2 \\
\hline Total & 0.5 & 0.6 & 0.2 & 0.8 & 0.2 & 0.1 & 2.2 \\
\hline \multicolumn{8}{|c|}{ All farmers (rural) } \\
\hline Poorest 30\% & 1.4 & 0.9 & 0.3 & 2.0 & 3.2 & 2.0 & 7.8 \\
\hline Middle 40\% & 0.3 & 0.5 & 0.2 & 1.1 & 1.6 & 1.0 & 3.7 \\
\hline Richest 30\% & 0.2 & 1.2 & 1.0 & 2.8 & 3.2 & 2.0 & 8.4 \\
\hline Total & 0.9 & 1.3 & 0.8 & 3.2 & 4.3 & 2.7 & 10.5 \\
\hline
\end{tabular}

Note: the change in total expenditures in the two surveys was decomposed into growth by source of income, using a change in total expenditures and applying the income structure in 2000 to this change in expenditures.

Source: Calculated from 1995-96 and 2000 HIES. 
Income growth of poor net sellers in excess of 3 percent is still somewhat puzzling as the direct impact of lower rice prices is negative on this household category. The low intensity of net sellers who are poor could explain this. As indicated in Figure 6, over 40 percent of the poorest rural households in the bottom decile of total per capita expenditures are in the least intense net seller category, with the value of rice sales between zero and 10 percent of total expenditures. This share is significantly lower for households in other deciles.

Figure 6. Intensity of net sellers of rice by income Percent of total expenditures

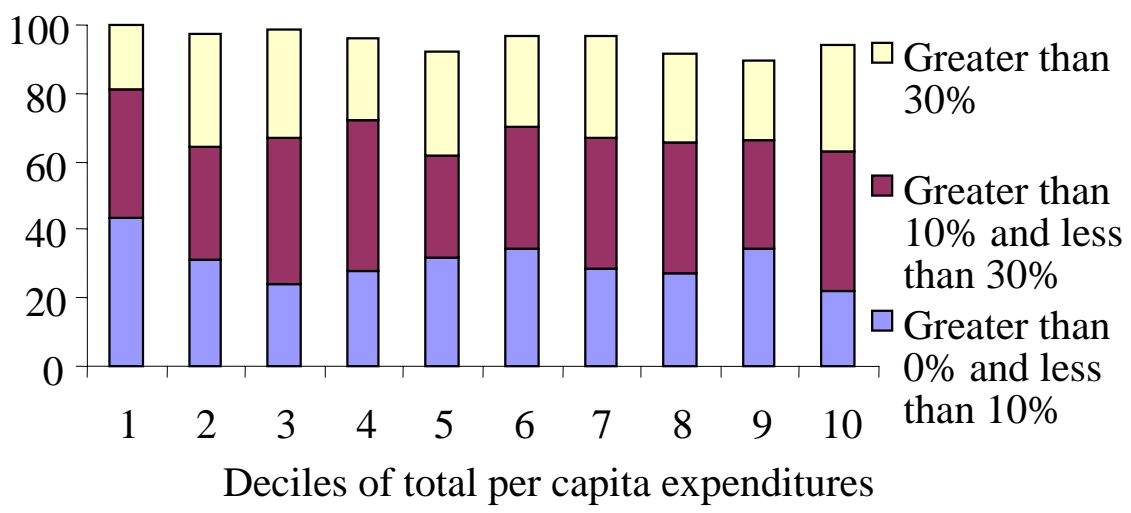

Note: Intensity is expressed as the value of rice sales net of purchases as percent of total expenditures. Totals do not always add to 100 percent because some households did not report any sales or purchases of rice and could not be categorized according to intensity of rice sales or purchases. Source: 2000 HIES (rural households).

Furthermore, a very small share of the poor rural net sellers of rice is in the category of highest intensity of net sales, with the value of rice sales exceeding 30 percent of total expenditures. The low intensity of the poorest rural net sellers is a plausible explanation of why their income has increased in spite of declining rice prices. Total income of poor rural net sellers could have also grown due to direct second-round (labor market) and multiplier effects.

Although growth incidence curves indicate the trends in income growth at different welfare levels, they provide no basis for establishing causality or even simply correlation with changes in productivity and rice prices. To establish this causality, we examine the impact on the change in total consumption of changes in rice productivity, 
producer and consumer prices of rice, a set of variables that describe the income structure, demographic characteristics, and the presence of irrigation and other infrastructure. We examine the correlation between these factors and the change in total consumption in the framework of a simple OLS regression, using a community-level panel data set with approximately 230 thana in rural areas that were included in the 199596 and 2000 HIES. In order to explore the differential effect of changes in prices and yields on different household categories within the framework of community-level panel data, we create three data sets by averaging the characteristics of the poor and the nonpoor and then pooling them into a single data set with approximately 460 observations. We proceed in the same way for farmers versus non-farmers and net sellers versus net buyers. We include a set of demographic control variables in the regression, as well as variables reflecting the production structure, dummy variables to control for unobserved heterogeneity by location and the economic variables of interest, such as percentage change in yields and prices and interactive variables of these changes with different household categories.

Regression results, shown in Appendix Table A3, reinforce the earlier finding that the poor have experienced significantly higher income growth than the non-poor (Model 1). Share of rice in irrigation, which reflects the production structure and the role of irrigation in the production process, has a positive significant effect on income growth for farmers compared to non-farmers (Model 2) and net sellers compared to net buyers (Model 3). Interestingly, having more women as a share of household size is associated with higher rates of income growth in Models 2 and 3, while the share of children has a positive effect on income of the net sellers/net buyers group and a negative effect on the poor/non-poor group. Furthermore, higher shares of remittances, agricultural wages and other income from non-agricultural sources income are associated with higher income growth. This finding might point to the significant role of multiplier effects and indirect labor market effects of the improvement in rice productivity observed in Bangladesh during this period.

Turning to the variables of most interest, we find that, as expected, the change in the price of paddy (i.e., producer price) has a significant impact only on farmer households and net sellers. It means that a smaller decline in the price of rice is 
associated with higher income growth for these groups of households. ${ }^{9}$ The impact of the producer price of rice is not significant for the poor/non-poor group. Somewhat surprisingly, we do not find that productivity improvements, measured by the change in rice yields, have a positive impact on income growth in Models 2 and 3 where we would expect them to matter, and they have a significant positive effect on income in Model 1.

High measurement error in the yield variable and sensitivity of yield changes to outliers even after the data have been cleaned may explain the lack of its significance in most model specifications. However, even conceptually a change in yields need not result in income growth. Farming household's profits are influenced by other factors such as fertilizer cost and application rate, wages paid to hired agricultural workers and unit labor requirements, capital and land, and the price of output. While productivity improvements have a positive impact on total output, they may not necessarily lead to higher profits and income growth. For example, Lopez (2000) has shown that an important rural development and poverty reduction program INDAP in Chile, designed to provide technical assistance or credit to farmers with high production potential, does not appear to have led to income growth. ${ }^{10}$ Although technical assistance and credit resulted in growth in production volume of crops that were supported by the program, these positive production effects dissipated into higher costs and less off-farm income. This was partly a result of a reduction in off-farm work by families that participated in INDAP programs. These findings underscore the need for an in-depth analysis of the relationship between increased productivity, profitability and income growth of rural households.

While results of the analysis of correlation between productivity, price changes and income growth in Bangladesh are not conclusive, much like the earlier results in this paper they suggest that the second-round direct effects in the labor market and indirect multiplier effects have been very significant in Bangladesh. Revisiting the archetype

\footnotetext{
${ }^{9}$ A positive coefficient means that an increase in the price change by one unit (so this negative number becomes smaller in absolute value) leads to an increase in total income. In other words, a smaller price decline results in a smaller reduction (or an increase) in total consumption (income).

${ }^{10}$ De Janvry and Sadoulet (2005) have recently shown that these findings should not lead to a conclusion that access to land is not important for poverty reduction and that programs that focus on improving access to land are not effective. The relationship between access to land and welfare improvements is heterogeneous, calling for a more sophisticated modeling approach that accounts for structural relationships and by different levels of access to infrastructure, education levels and other endowments and skills. Once these factors are adequately controlled for, they find a positive relationship between access to land and income growth in Mexico.
} 
models of an economy suggested by De Janvry and Sadoulet (2002), we may conclude that Bangladesh combines some features of Asian and Latin American archetype countries. They postulated that in Asia indirect agricultural employment effects are likely to be large owing to a large pool of landless wage workers in rural areas, and in Latin America the dominant effect of productivity improvements is through multiplier effects, both of which seem to be true in the case of Bangladesh.

\section{Conclusion}

Increasing the purchasing power of rural dwellers is central for poverty reduction in Bangladesh because the majority of the poor live in rural areas. Despite the structural transformation of the Bangladeshi economy and the declining role of agriculture, the latter is still the most direct vehicle to reduce poverty. Over half of Bangladesh's working population still depends on agriculture for livelihood and income and the sector's contribution to overall growth is still important. Because rice constitutes over half of real agriculture GDP and it is Bangladesh's major staple food, any policy change that affects the rice economy is bound to have important poverty impacts.

Using a combination of ex-post and ex-ante approaches and Bangladesh's 1996 and 2000 household surveys, we analyze the distributional impacts of major trade reforms directed on rice markets undertaken in the early 1990s. The liberalization of trade in irrigation equipment and fertilizer markets has indeed led to a significant increase in rice productivity and a sharp decline in producer and consumer rice prices. We examine the effect on net consumers, net sellers of rice, non-farmers and farmers. We find that rural households who are net consumers of rice have experienced an increase in income. Income growth between 1995-96 and 2000 has tended to be pro-poor for this group. Net sellers of rice have experienced a decline in the income level, while income of the poor households in the poor/non-poor model has increased. A possible explanation for this are greater employment opportunities in the rural non-farm sector and higher agricultural wages, which members of poor households are more likely to be affected by.

Our findings suggest that for some categories of households income changes can be attributed to the changes in productivity and rice prices. Since net buyers in rural areas tend to be poorer than net sellers, productivity improvements induced by trade 
liberalization and the associated direct and indirect secondary effects have benefited the poor. Although we are not able to test empirically what has happened to the welfare level of agricultural wage earners, secondary evidence suggests that they have gained from trade liberalization. That income of non-farmers in rural areas has increased would support this claim.

Despite important data constraints related to the comparability of the 1995/96 and the 2000 surveys, our results shed some light on the somewhat small reduction in overall poverty despite substantial economic growth in Bangladesh during the 1990s. Indeed, the major positive impact of the trade reforms analyzed in the paper falls on the rural landless farmers. This category featured Bangladesh's highest incidence of extreme poverty in the early 1990s so that the major impact of trade reform may have been to lift a large number of extreme poor to the poverty category. This issue deserves further investigation. The current household survey being finalized could provide useful insights into it. 


\section{References}

Ahmed, Said and Zaidi Sattar (2003). “Trade Liberalization, Growth and Poverty Reduction. The Case of Bangladesh.” South Asia Region Internal Discussion Paper. The World Bank, Washington, D.C.

Barrett, Christopher and Paul Dorosh (1995). "Rice Prices and Farmers' Welfare in Madagascar: A Nonparametric Analysis.” Cornell Food and Nutrition Policy Program Working Paper No. 73.

Boyce, J. and Martin Ravallion (1988). "Wage Determination in Rural Bangladesh: Effects of Relative Prices and Agricultural Productivity.” Agricultural Policies Division. Policy, Planning, and Research. The World Bank, Washington, D.C. Mimeographed.

Datt, Gaurav and Martin Ravallion (1998). "Farm Productivity and Rural Poverty in India.” The Journal of Development Studies. Vol. 34: 62-85.

Deaton, Angus (1989). "Rice Prices and Income Distribution in Thailand: A NonParametric Analysis.” The Economic Journal. Vol. 99: 1-37.

De Janvry, Alain and Elisabeth Sadoulet (2002). "World Poverty and the Role of Agricultural Technology: Direct and Indirect Effects.” The Journal of Development Studies. Vol. 38: 1-26.

De Janvry, Alain, Elisabeth Sadoulet and Gustavo Cordillo de Anda (1995). "NAFTA and Mexico’s Maize Producers.” World Development. Vol. 23. No. 8: 1349-1365.

Del Ninno, Carlo and Paul Dorosh (2003). "Public Policy, Market and Household Coping Strategies in Bangladesh: Avoiding a Food Security Crisis Following the 1998 Floods.” World Development. Vol. 31: 1221-1238.

Delgado, Christopher, Jane Hopkins and Valeri Kelly with Peter Hazell, Anna McKenna, Peter Gruhn, Behjat Hojjati, Jayashree Sil, and Claude Courbois (1998). “Agricultural Growth Linkages in Sub-Saharan Africa.” Research Report No. 107. International Food Policy Research Institute. Washington, D.C.

Dorosh, Paul (2001). "Trade Liberalization and National Food Security: Rice Trade Between Bangladesh and India.” World Development. Vol. 29. No. 4: 673-689.

Dorosh, Paul (2004). "Trade, Food Aid and Food Security. Evolving Rice and Wheat Markets.” Economic and Political Weekly. Vol. 29: 4033-4042.

Dwayne, Benjamin and Angus Deaton (1993). "Household Welfare and the Pricing of Cocoa and Coffee in Cote d'Ivoire: Lessons from the Living Standards Surveys.” The World Bank Economic Review. Vol. 7. No. 3: 293-318.

Edmonds, Eric and Nina Pavcnik (2004). "Trade Liberalization and the Allocation of Labor between Households and Markets in a Poor Country.” Department of Economics, Dartmouth College.

Finan, Frederico, Alain De Janvry, and Elisabeth Sadoulet (2005). "Measuring the Poverty Reduction Potential of Land in Rural Mexico.” Journal of Development Economics 77, no. 1: 27-51.

Gisselquist, D. and Harun-ar-Rashid (1998). “Agricultural Inputs Trade in Bangladesh: Regulations, Reforms and Impacts.” The World Bank, Washington, D.C. Mimeographed.

Lopez, Ramon (2000). "Determinants of Rural Poverty in Chile: Evaluating the Role of Public Extension/Credit Programs and Other Factors.” In: Lopez, Ramon and 
Alberto Valdez, eds. Rural Poverty in Latin America. St. Martin’s Press, New York.

Minten, Bart and Christopher Barrett (2005). "Agricultural Technology, Productivity, Poverty and Food Security in Madagascar.” Mimeographed.

Mujeri, M.K. (2002), 'Globalization-Poverty Links in Bangladesh: Some Broad Observations', in A Review of Bangladesh's Development 2001, Centre for Policy Dialogue/University Press Limited, Dhaka.

Murgai, Rinku and Salman Zaidi (2004). "Poverty Trends in Bangladesh During the Nineties.” Poverty Reduction and Economic Management Unit, South Asia Region. World Bank Report no. 30863. Mimeographed.

Nicita, Alessandro (2005). "Export Led Growth, Pro-Poor or Not? Evidence from Madagascar's Textile and Apparel Industry.” Policy Research Working Paper (forthcoming). The World Bank, Washington, D.C.

Porto, Guido (2005). "Estimating Household Responses to Trade Reforms. Net Consumers and Net Producers in Rural Mexico." Policy Research Working Paper No. 3695. The World Bank, Washington, D.C.

Ravallion, Martin (2004). "Pro-Poor Growth: A Primer." Policy Research Working Paper No. 3242. The World Bank, Washington, D.C.

Ravallion, Martin and Shaohua Chen (2003). "Measuring Pro-Poor Growth." Policy Research Working Paper 2666. The World Bank, Washington, D.C.

Ravallion, Martin and Gaurav Datt (1998). "Farm Productivity and Rural Poverty in India”, FCND discussion Paper No. 42, International Food Policy Research Institute, Washington, D.C.

Ravallion, Martin and Michael Lokshin (2004). "Gainers and Losers from Trade Reform in Morocco.” Middle East and North Africa Working Paper No. 37. The World Bank. Washington, D.C.

Thamarajakshi, R. and Martin Ravallion (1991). "The Relation Between Rice Prices and Wage Rates in Bangladesh.” Working Papers on Food Policy in Bangladesh, No. 2. International Food Policy Research Institute. Washington, D.C.

Seshan, Ganesh (2005). "The Impact of Trade Liberalization on Household Welfare in Vietnam.” Policy Research Working Paper No. 3541. The World Bank, Washington, D.C.

Siamwalla, A. (1982). “Growth Linkages: A Trade-Theoretic Approach.” International Food Policy Research Institute. Washington, D.C. Mimeographed.

Winters, Alan (2002). “Trade Liberalization and Poverty: What are the Links?” mimeo:1339-1367.

World Bank (2002a). "Poverty in Bangladesh: Building on Progress.” Poverty Reduction and Economic Management Sector Unit Report. Washington, D.C.

World Bank (2002b). "Agricultural Growth and Rural Poverty Dynamics: A Regional Perspective.” South Asia Rural Development Unit Draft Report. Washington, D.C.

World Bank (2004). "Bangladesh. Promoting the Rural Non-Farm Sector in Bangladesh.” Report No. 29719-BD. The World Bank. Washington, D.C. 


\section{Appendix 1: Tables and figures}

Table A1. Change in yields of rice (total annual production in kg/acre).

\begin{tabular}{lcccc}
\hline & $\begin{array}{c}\text { Average } \\
\text { production } \\
\text { in 1995 } \\
(\mathrm{kg} / \text { acre })\end{array}$ & $\begin{array}{c}\text { Average } \\
\text { production } \\
\text { in 2000 } \\
(\mathrm{kg} / \text { acre })\end{array}$ & $\begin{array}{c}\text { Average } \\
\text { change in } \\
\text { production } \\
\text { (kg/acre) }\end{array}$ & $\begin{array}{c}\text { Median } \\
\text { percent } \\
\text { change } \\
(\%)\end{array}$ \\
\hline $\begin{array}{l}\text { Northwest } \\
\text { South Ganges }\end{array}$ & 1,710 & 2,581 & 872 & 41 \\
Floodplain & 1,124 & 2,294 & 1,169 & 69 \\
Coastal & 1,084 & 2,626 & 1,542 & 131 \\
North Central & 1,486 & 2,631 & 1,144 & 45 \\
Meghna Floodplain & 1,841 & 2,349 & 509 & 26 \\
All regions & 1,517 & 2,504 & 987 & 42 \\
\hline
\end{tabular}

Note: statistics reported in this table are sensitive to the presence of outliers even after dropping observations that are more than 5 standard deviations away from the mean of the data and should be interpreted with caution. Source: thana-level panel combining 1995-96 and 2000 HIES.

Table A2. Poverty incidence by household type in Bangladesh.

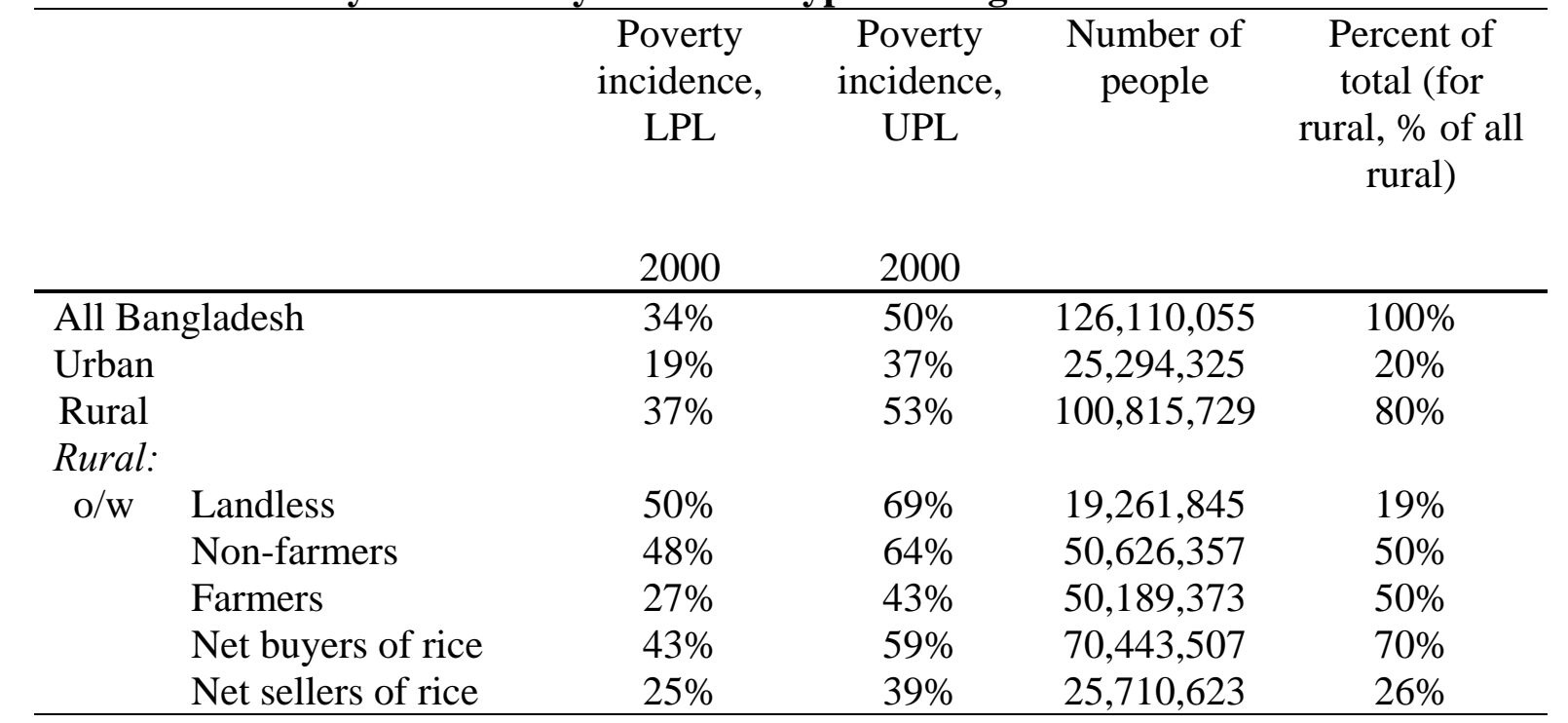

Note: Weighted data using individual weights. Landless are defined as households with less than 0.1 acres of land in cultivation (functionally landless). Net sellers of rice are households whose annual rice sales gross income exceeds expenditures on rice purchases.

Source: 1995-96 and 2000 HIES. 
Table A3. Determinants of the change in total household expenditures (OLS regression results). $1 /$

\begin{tabular}{|c|c|c|c|}
\hline & Model 1 2/ & Model 2 & Model 3 \\
\hline & $\begin{array}{l}\text { Poor vs. } \\
\text { Non-poor }\end{array}$ & $\begin{array}{l}\text { Farmers vs. } \\
\text { Non-farmers }\end{array}$ & $\begin{array}{c}\text { Net sellers } \\
\text { vs. net buyers }\end{array}$ \\
\hline \multicolumn{4}{|l|}{ Group dummy variables: } \\
\hline$\overline{\text { Poor (bottom 30\%) }}$ & $\begin{array}{l}578.582 \\
(2.73) * *\end{array}$ & & \\
\hline Farmer & & $\begin{array}{l}1,874.98 \\
(4.26)^{* *}\end{array}$ & \\
\hline Net seller & & & $\begin{array}{c}660.496 \\
(1.44)\end{array}$ \\
\hline \multicolumn{4}{|l|}{ Economic variables: } \\
\hline Change in yield & $\begin{array}{c}0.15 \\
(2.82)^{* *}\end{array}$ & $\begin{array}{l}0.083 \\
(1.12)\end{array}$ & $\begin{array}{l}0.048 \\
(0.66)\end{array}$ \\
\hline Change in price of paddy & $\begin{array}{c}23.769 \\
(0.50)\end{array}$ & $\begin{array}{l}0.741 \\
(0.02)\end{array}$ & $\begin{array}{r}55.08 \\
(0.89)\end{array}$ \\
\hline Share of rice in irrigation & $\begin{array}{l}0.162 \\
(1.39)\end{array}$ & $\begin{array}{c}0.466 \\
(3.12)^{* *}\end{array}$ & $\begin{array}{c}0.361 \\
(2.73)^{* *}\end{array}$ \\
\hline Share with access to electricity & $\begin{array}{c}69.288 \\
(0.54)\end{array}$ & $\begin{array}{c}189.739 \\
(1.02)\end{array}$ & $\begin{array}{c}301.416 \\
(1.27)\end{array}$ \\
\hline \multicolumn{4}{|l|}{ Interactive: } \\
\hline Change in yield*poor & $\begin{array}{l}-0.104 \\
(1.74)\end{array}$ & & \\
\hline Change in price*poor & $\begin{array}{c}36.733 \\
(0.69)\end{array}$ & & \\
\hline Change in yield*farmer & & $\begin{array}{l}-0.004 \\
(0.04)\end{array}$ & \\
\hline Change in price*farmer & & $\begin{array}{l}347.397 \\
(4.31)^{* *}\end{array}$ & \\
\hline Change in yield*net seller & & & $\begin{array}{l}0.050 \\
(1.04)\end{array}$ \\
\hline Change in price*net seller & & & $\begin{array}{c}475.63 \\
(5.13)^{* *}\end{array}$ \\
\hline \multicolumn{4}{|c|}{ Demographic and income structure: } \\
\hline Household size & $\begin{array}{l}76.803 \\
(0.86)\end{array}$ & $\begin{array}{c}88.965 \\
(0.67)\end{array}$ & $\begin{array}{l}-551.088 \\
(4.18) * *\end{array}$ \\
\hline Percent of females & $\begin{array}{l}14.253 \\
(1.76)\end{array}$ & $\begin{array}{l}37.775 \\
(2.64)^{* *}\end{array}$ & $\begin{array}{c}52.433 \\
(3.38)^{* *}\end{array}$ \\
\hline Percent of children & $\begin{array}{l}-28.543 \\
(3.78) * *\end{array}$ & $\begin{array}{l}2.443 \\
(0.22)\end{array}$ & $\begin{array}{l}27.277 \\
(2.13)^{*}\end{array}$ \\
\hline \multicolumn{4}{|c|}{$\begin{array}{l}\text { Income structure (shares of total income in } \\
\text { 1995): }\end{array}$} \\
\hline Remittances & $\begin{array}{l}8.576 \\
(0.69)\end{array}$ & $\begin{array}{l}38.499 \\
(2.16)^{*}\end{array}$ & $\begin{array}{l}13.452 \\
(0.79)\end{array}$ \\
\hline
\end{tabular}


Agricultural wages

Non-agricultural wages

(0.86)

(3.10)**

Non-rice ag. products

3.123

20.594

11.077

(0.30)

(1.42)

(0.92)

Non-rice ag. products

$-6.249$

$-9.33$

$-10.716$

$(0.52)$

(0.55)

(0.73)

Other sources (non-agricultural)

5.679

30.124

2.383

(0.56)

(2.11)*

(0.23)

Location specific characteristics (Northwest is the omitted regional

dummy):

\begin{tabular}{|c|c|c|c|}
\hline South Ganges region & $\begin{array}{c}181.856 \\
(0.92)\end{array}$ & $\begin{array}{c}402.181 \\
(1.38)\end{array}$ & $\begin{array}{c}619.071 \\
(1.74)\end{array}$ \\
\hline \multirow[t]{2}{*}{ Coastal region } & 585.48 & $1,512.89$ & 1751.327 \\
\hline & $(2.50)^{*}$ & $(4.38) * *$ & $(4.21)^{* *}$ \\
\hline \multirow[t]{2}{*}{ North Central region } & 116.656 & 108.135 & 267.801 \\
\hline & $(0.68)$ & $(0.43)$ & $(0.86)$ \\
\hline \multirow[t]{2}{*}{ Meghna Flood Plain } & 688.411 & $1,242.57$ & 2004.753 \\
\hline & $(3.18) * *$ & $(3.92)^{* *}$ & $(5.26)^{* *}$ \\
\hline \multirow[t]{2}{*}{ East Hills region } & 39.65 & 551.676 & $1,357.78$ \\
\hline & $(0.11)$ & $(1.06)$ & $(2.31)^{*}$ \\
\hline \multirow[t]{2}{*}{ Constant } & $-1,003.46$ & $-6,185.50$ & 1533.28 \\
\hline & $(0.85)$ & $(3.62) * *$ & $(1.80)$ \\
\hline Observations & 461 & 465 & 453 \\
\hline R-squared & 0.13 & 0.20 & 0.33 \\
\hline \multicolumn{4}{|c|}{$\begin{array}{l}\text { Notes: } \\
\text { 1/ Dependent variable is change in total household expenditures, } 2000 \mathrm{Tk} / \text { month (thana averages). Absolute } \\
\text { value of t statistics in parentheses; * significant at } 5 \% \text {; ** significant at } 1 \% \text {. } \\
2 \text { / Calculated from a thana-level panel dataset that was created from the } 1995-96 \text { and } 2000 \text { HIES by first } \\
\text { creating a data set with the average characteristics for the poor at the thana level, then the non-poor, and then } \\
\text { pooling the two data sets and running a regression in Model } 1 \text {. A similar procedure was used to create the } \\
\text { data sets used in Models } 2 \text { and } 3 \text {. Approximately } 230 \text { rural thana were used to create the data set. (There is a } \\
\text { total of } 295 \text { thana in the survey, of which } 250 \text { are completely or partly rural, and the rest urban and so } \\
\text { excluded from this analysis. In approximately } 20 \text { thana dependent variables were missing, so they are also } \\
\text { excluded from the analysis.) }\end{array}$} \\
\hline
\end{tabular}

2004.753

$(5.26)^{* *}$

(2.31)*

1533.28

R-squared

\subsection{3}

465

Notes: value of $\mathrm{t}$ statistics in parentheses; * significant at $5 \%$; ** significant at $1 \%$.

2/ Calculated from a thana-level panel dataset that was created from the 1995-96 and 2000 HIES by first creating a data set with the average characteristics for the poor at the thana level, then the non-poor, and then pooling the two data sets and running a regression in Model 1. A similar procedure was used to create the data sets used in Models 2 and 3. Approximately 230 rural thana were used to create the data set. (There is a excluded from this analysis. In approximately 20 thana dependent variables were missing, so they are also excluded from the analysis.) 
Figure A1. Real Rice and Wholesale Wheat Prices.

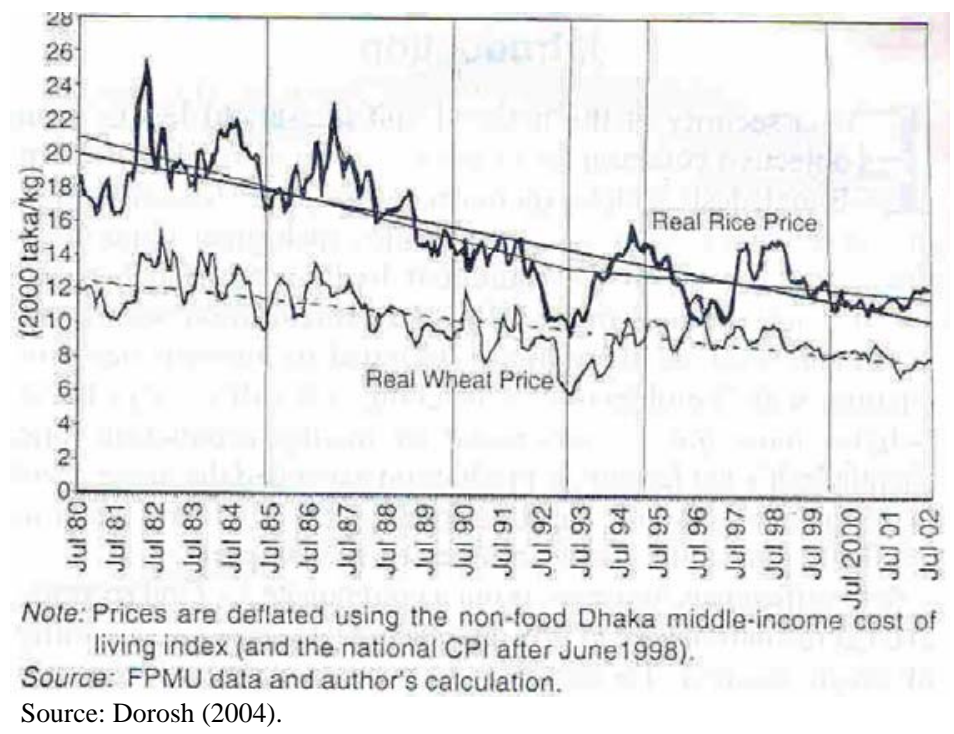




\section{Appendix 2: Data Sources}

\section{Comparability of the 1995-96 and 2000 Household Surveys}

The survey design is significantly different in the 2000 HIES from the 1995-96 HIES. In the 1995-96 survey most rural households report having some cultivated land and producing crops, while the share of such households in the 2000 survey is much lower, as shown in Appendix Table A4.

\begin{tabular}{|c|c|c|c|c|c|c|}
\hline & \multicolumn{2}{|c|}{$\begin{array}{c}\text { Positive } \\
\text { cultivated land }\end{array}$} & \multicolumn{2}{|c|}{ Positive production } & \multicolumn{2}{|c|}{$\begin{array}{c}\text { Positive ag. } \\
\text { wages }\end{array}$} \\
\hline & 1995 & 2000 & 1995 & 2000 & 1995 & 2000 \\
\hline All rural & 65 & 49 & $72(89)$ & 69 & 35 & 33 \\
\hline Non-farmer & 40 & 6 & $57(82)$ & 43 & 37 & 40 \\
\hline Net seller & 95 & 85 & 92 & 100 & 24 & 25 \\
\hline Net buyer & 48 & 29 & 62 & 52 & 41 & 38 \\
\hline Small farmer & 100 & 100 & $93(100)$ & 100 & 43 & 33 \\
\hline Medium farmer & 100 & 100 & $96(100)$ & 99 & 22 & 11 \\
\hline Large farmer & 100 & 100 & $94(100)$ & 100 & 14 & 9 \\
\hline
\end{tabular}

Note: Weighted data. Calculated from 1995-96 and 2000 HIES.

Rather than relying solely on the cultivated area to classify households as farmers, we combined this criterion with the question about occupational status. Still, we needed to address the issue of comparability of the reported cultivated land in two surveys. The way this question was posed in 1995, the respondents reported all land that is owned and/or cultivated, while only half of all rural households report having cultivated land. The reasons for this discrepancy in the way the question about land was answered are not entirely clear. Possibly, the 1995 survey respondents reported cultivated land that is not their own, but belongs to the owner for whom they work for wages. Alternatively, land ownership may be under-reported in the 2000 survey. The fact that the average land size of 1.25 acres in 1995 is significantly higher than the average land size of 1.12 in 2000 supports this hypothesis. Using "net land with temporary crops" in the 1995 survey and "total net cultivable agricultural land" results in greater comparability of land sizes in the two surveys. The figures in Appendix Table A4 for 1995 and all other statistics related to the land size are based on the definition of total land as "net land with temporary crops" in 1995. This definition results in comparable average sizes of cultivated land for small, medium, large farmers and non-farmers.

Production figures were initially not comparable either. Before making any adjustments to the data, 89 percent of all rural households reported positive production in 1995, and only 69 percent in 2000 (Appendix Table A4). This discrepancy is due to the fact that some households who should have been reporting income as agricultural wages in 1995 reported them as own production revenues. Using the reported employment status, we identified a group of these households, and counted their production revenues 
as agricultural wages instead of agricultural revenues. After this correction, the shares of all rural households with positive production are comparable at 72 and 69 percent. The old shares before this correction are shown in brackets. Even though some further refinement is possible, it is not necessary because we are not using total production or agricultural wage figures in the analysis. The purpose of this adjustment was to illustrate that the data sets are comparable, although the land figures should be interpreted with caution.

In order to analyze changes in yields and other conditions for the farmer households between 1995-96 and 2000, we need to define farming households consistently in the two surveys. We have done this by combining information about the occupational status and the sector of employment of household members with information about the size of cultivated land. We have tried alternative definitions, and this one was found to result in the greatest comparability between the farmer households in the two surveys.

In the 1995-96 survey, we define a household as a farmer household if at least one household member reports having an occupation other than an agricultural worker with no land working for wages or on contract basis, or a non-working land owner (question Q.7). In the 2000 survey, respondents are defined as farming households when at least one member reports being a farmer (question 1 in section 5) who is self-employed in agriculture (question 6 in section 5). In addition, households with over one third of total household income resulting from agricultural production are classified as farmer households. 